\title{
Nurettin Topçu'nun Demokrasi Kavramına Yönelik Eleştirisi
}

\section{The Critiques of Nurettin Topçu on the Concept of Democracy}

\author{
Can Karaböcek ${ }^{1}$ (D)
}

'(Doç.Dr.), Kırklareli Üniversitesi, Fen Edebiyat Fakültesi, Felsefe Bölümü, Kırklareli, Türkiye

ORCID: C.K. 0000-0001-8202-5209

\section{Sorumlu yazar/Corresponding author:} Can Karaböcek

Kırklareli Üniversitesi, Fen Edebiyat Fakültesi,

Felsefe Bölümü, Kırklareli, Türkiye

E-posta/E-mail: cankarabck@gmail.com

Başvuru/Submitted: 06.05.2021

Revizyon Talebi/Revision Requested:

03.06.2021

Son Revizyon/Last Revision Received:

03.06.2021

Kabul/Accepted: 04.06.2021

Atıf/Citation: Karabocek, Can. "Nurettin Topçu'nun Demokrasi Kavramına Yönelik Eleştirisi." Felsefe Arkivi- Archives of Philosophy, 54 (2021): 49-61.

https://doi.org/10.26650/arcp.933882

\section{ÖZET}

Yirminci yüzyıl Türk düşüncesinin Anadolucu milliyetçiliğinin önemli bir figürü olan Nurettin Topçu'nun ahlak, din ve irade ve eğitim konusundaki görüşleri oldukça sık irdelenmiş ve bu alanda düşüncesinin özgünlüğünü ortaya koyan pek çok çalışma olmasına rağmen onun parlamenter demokrasi fikrine yönelik görüşlerini ele alan çalışma sayısı pek fazla değildir. Topçu'nun benimsediği Anadoluculuk fikri 20 . Yüzyılın başında ortaya çıkmış bir düşünsel akımdır ve farklı Anadoluculuk ekollerinin varlığından söz edilebilir. Topçu'nun ruhçu milliyetçi sosyalist bir Anadoluculuk fikrini savunması, onu diğer milliyetçi yaklaşımlardan farkıı kılmaktadır. Özellikle Topçu'daki kapitalizm eleştirisi onun parlamenter demokrasi fikrine de eleştirel yaklaşmasına neden olmuştur. Nurettin Topçu geliştirdiği devlet anlayışı çerçevesinde demokrasiyi milliyetçiliğe aykıı bir sistem olarak görür ve bu yönden eleştirir. Bu eleştirinin sonucu olarak da parlamenter demokrasiye dayalı çoğulcu bir siyasal yapı yerine; korporatif otoriter bir siyasal sistemi önerir. Bu makalede düşünürün milliyetçilik anlayışı diğer milliyetçilik anlayışlarından ayrıldığı noktaları ortaya koyarak, kapitalizm eleştirisine dayalı olarak parlamenter demokrasi fikrine getirdiği eleştirileri ele alacağız ve parlamenter demokrasi yerine otoriter bir korporatizmi önerdiğini göstermeye çalışacağız. Bu çerçevede yazarın demokrasi kavramına getirdiği eleştirinin de popülist bir romantizm temelinde getirilen bir eleştiri olduğu gösterilmeye çalışılacaktır.

Anahtar Kelimeler: Romantizm, parlamenter demokrasi, milliyetçilik, otoriter devlet, kapitalizm

\section{ABSTRACT}

Nurettin Topçu is an important figure of the Anatolian nationalism of the 20th century. Scholars have frequently examined Turkish thought, views on morality, religion, will, and education. Although many studies have revealed the originality of his thought in this area, studies addressing his views on the concept of parliamentary democracy are few. The idea of Anatolianism, as adopted by Topçu, is an intellectual movement that emerged at the beginning of the 20th century, such that various schools of Anatolianism have been established. Topçu's advocacy of a spiritual, nationalist, and socialist Anatolianism idea makes him different from other nationalist approaches. 
In particular, the criticism of capitalism in Topçu's thought critically led to the formulation of the idea of parliamentary democracy. Nurettin Topçu has regarded democracy as an anti-nationalist system within the framework of the understanding of the state he developed within the framework of populist romanticism and criticizes it from this point of view. As a result of such a criticism, he has proposed an authoritarian corporate state system instead of a pluralist political structure based on parliamentary democracy. This study puts forward the points where Topçu's nationalism differs from other conceptions of nationalism. Moreover, the study examines Topçu's criticism of the idea of parliamentary democracy is based on a critique of capitalism and demonstrates that he proposes an authoritarian corporatism instead of parliamentary democracy. Using this framework, the study intends to illustrate that the author's criticism of the concept of democracy is also a criticism resulting from populist romanticism.

Keywords: Romanticism, Parliamentary democracy, nationalism, authoritarian state, capitalism

\section{EXTENDED ABSTRACT}

Nurettin Topçu is an important figure of Anatolian nationalism during the 20th century. Many scholars have examined Turkish thoughts, views on morality, religion, will, and education. Although the literature reveals the originality of his thought in this area, studies that focused on his views on the idea of parliamentary democracy are few. The idea of Anatolianism purported by Topçu is an intellectual movement that emerged at the beginning of the 20th century, and many schools of Anatolianism were constructed. Topçu's advocacy of a spiritual, nationalist, and socialist Anatolianism idea makes him stand out from other nationalist approaches. Although Topçu is a nationalist thinker, his nationalism differs from Turkish nationalism. No systematic racism existed in Topçu's nationalism, and he criticized the Turkish thought of his time. Therefore, the study infers on the presence of an extremely strong anti-Semitism in his own thought. Although he strongly criticized biological racism, encountering the exclusion and moral criticism of certain ethnic groups in his thoughts is easy. The belief in Islam is an integral part of Topçu's nationalism. Topçu, who holds a mystical understanding of Islam, criticizes capitalism on this basis and intends to develop an anti-capitalist nationalism. In particular, the criticism of capitalism in Topçu's thought critically encouraged him to approach the concept of parliamentary democracy critically. Topçu is critical of modernism as well as capitalism and proposes a pastoral sociality where organic solidarity prevails instead of mechanical solidarity as an alternative to modernism. He advocates a political organization based on social leaders, which he conceptualizes as a nation mystic. Viewing pluralist parliamentary democracy as a result of capitalism, Topçu also directs his criticism of capitalism to parliamentary democracy. Moreover, Topçu's critique of parliamentary democracy is a result of his critique of capitalism. Instead, of a political organization based on the feudal mode of production, which was abolished by the capitalist mode of production, it objects to the idea of parliamentary democracy, which is the basic element of the political sphere that was reshaped by the bourgeois class. The strong critique of capitalism found in Topçu's thought does not lead him to a Marxist critique. Instead, Nurettin Topçu regards democracy as an anti-nationalist system within the framework of the understanding of the state he developed within the framework of populist romanticism and criticizes it from this point of view. As a result of this criticism, he proposes an authoritarian corporate state system instead of a pluralist 
political structure based on parliamentary democracy. Topçu objects the alienation of man from his existence as a result of the instrumentalization of man and the consideration of capital as the highest value instead of labor in the capitalist mode of production and the social political organization model created by it. Thus, he aims for the elimination of this alienation in the corporate state system. This study presents the points where Topçu's nationalism differs from other conceptions of nationalism and examines Topçu's criticism of the idea of parliamentary democracy based on a critique of capitalism. Furthermore, the study intends to demonstrate that he proposes an authoritarian corporatism instead of parliamentary democracy. Using this framework, the study illustrates that the author's criticism of the concept of democracy is also a criticism resulting from brought populist romanticism. Lastly, this study reveals the similarities between Topçu's national socialism and German national socialism, and reveals that Topçu's criticism of democracy does not result in fascism. In other words, his objection to parliamentary democracy cannot be characterized as fascism because he provides freedom of thought with an essential place and harshly criticizes the political use of violence. 


\section{GİRIŞ}

20. Yüzyıl Türk düşüncesinin ayrıksı bir figürü olan Nurettin Topçu’ya yönelik ilginin son yıllarda arttığını gözlemleyebiliriz. Özellikle Türkiye'deki İslamcı-muhafazakar düşünce çevresi içerisinde Topçu'nun düşüncesi giderek daha fazla dikkat çekmeye başlamıştır. Topçu'nun İslâm, ahlak, insan, eğitim, milliyetçilik gibi konulardaki görüşleri bu bakımdan daha sıklıkla anılır olmuştur. Bu makalede Topçu'nun siyaset anlayışı çerçevesinde devlet anlayışına bağlı olarak demokrasi fikrine yönelik itirazları ele alınarak, düşünürün demokrasi fikrine yönelik eleştirilerinin otoriter korporatif bir devlet anlayışına yol açabileceği gösterilmeye çalışılacaktır.

\section{Nurettin Topçu'nun Felsefi Arka Planı}

Nurettin Topçu 1909 yılında Erzurumlu bir ailenin çocuğu olarak İstanbul'da doğdu. İlk, orta ve lise tahsilini İstanbul'da yaptı ve İstanbul Erkek Lisesi'nden mezun olduktan sonra 1928 yılında Milli Eğitim Bakanlığı’nın yükseköğrenim görmek üzere Avrupa’ya gönderdiği gençler arasına girerek, felsefe eğitimi yapmak üzere Fransa’ya gönderildi. 1934 yılında Maurice Blondel danışmanlığında hazırladığı doktora tezini başarı ile savunarak Sorbornne Üniversite'sinden mezun oldu. Danışmanı olan Blondel ve Fransa da tanıştığı Louis Massignon düşünceleri üzerinde oldukça etkili olmuştur. Katolik bir filozof olan Blondel'in hareket felsefesinden oldukça etkilenmiş ve Hallâc-1 Mansur üzerine çalışması da bulunan Massignon'un tasavvufi yorumu Topçu'nun düşüncesini oluşturmada oldukça etkili olmuştur. Danışmanı olan Blondel'in' Şarkta en az bir asır daha felsefe yapılmaz' diyerek Fransa'da kalması yönündeki teklifini reddetmiş ve Türkiye’ye dönmüştür. Avrupa'daki tahsilini başarı ile tamamlayan öğrenciler İstanbul Üniversitesinde görevlendirilirken, kendisi istemesine rağmen İstanbul Üniversitesi’nde görevlendirilmeyerek ${ }^{1}$, Galatasaray Lisesinde Felsefe Öğretmeni olarak görevlendirildi. Bu görevi esnasında, okul müdürünün, dönemin hatırlı kişilerin çocuklarının notlarının yükseltilmesi talebini reddetmesi sonucunda, BMM’nin ilk dönem vekillerinden olan Hüseyin Avni Ulaş'ın kızı Fethiye Hanım ile evlendiği gün, İzmir Lisesi'ne tayini çıkartılmıştır. ${ }^{2}$ İzmir'de görev yaparken daha sonra yıllarca kendi görüşlerini ortaya koyacağı Hareket dergisini çıkarmaya başladı. Derginin 4. sayısında yayınlanan 'Çalgıcılar' adlı hikâyesinden dolayı tekrar tayini çıkartılarak İstanbul Vefa Lisesine görevlendirildi. ${ }^{3}$ Vefa Lisesinde 4 yıl çalıştıktan sonra Denizli’ye tayini çıkar ve orada Said-i Nursi ile tanışır. Ancak Topçu'nun yaşamında oldukça etkili olmuş asıl dinî figür Nakşi şeyhi Abdulaziz Bekkine'dir. Aralarında Bekkine’nin vefatına kadar sürecek derin bir dostluk ve fikir alışverişi olacaktır. Denizli'de bir yıl çalıştıktan sonra tayini İstanbul Erkek Lisesi'ne çıkar. Daha sonra tekrar Vefa Lisesi'nde, Haydarpaşa Lise'sinde ve son olarak da emekli oluncaya dek İstanbul Erkek Lisesi'nde çalışır. Bunların dışında ek görev olarak uzun yıllar Robert Kolej'de ve İstanbul İmam Hatip Okulu’nda dersler vermiştir. Öğretmenlik görevini devam ettirirken 1947

1 Bunun nedeni, Nurettin Topçu'nun Cumhuriyetin kurucu kadrolarının politik yaklaşımı ile uyumlu olmayan bir tutuma sahip olması olarak yorumlanabilir.

2 Bkz. İsmail Kara, "Ahlâk Davasına ve Muallimliğe Adanmış Bir Ömür: Nurettin Topçu”, Temaşa Erciyes Üniversitesi Felsefe Bölümü Dergisi 4 (2016), 10.

3 Bkz. A.g.e., s.11 ayrıca Ezel Erverdi, Nurettin Topçu: Dünden Kalanlar ve Geleceğe Umutlar, (İstanbul: Dergâh Yay, 2018) 431-435. 
yılında 'Sezgiciliğin Değerleri' başlıklı tez ile doçent olmuştur. Topçu'nun bu tezi Türkiye'deki ilk felsefe doçentlik tezidir ve kabulünden çok sonra 'Bergson't adıyla kitap olarak basılmıştır.' Doçentlik tezinin kabulüne rağmen kendisine üniversitede görev verilmemiş ve öğretmenlik görevine devam etmiştir. 1961 yılında Adalet Partisi'nden Konya’dan senatör adayı olmuş ancak seçilememiştir. Öğretmenlik görevine devam ederken yazılı üretimine çoğunlukla kendi kurduğu Hareket Dergisi'nde devam etmiş, oldukça üretken bir yazar olan Nurettin Topçu 1975 yılında İstanbul'da vefat ettiği yıla kadar ardında çok sayıda eser bırakmıştır.

Topçu'nun İsyan Ablâkı adlı eserinde kendisini gösteren irade fikri ile harmanlanmış kişi anlayışı, onu bireye dayalı toplumsallık fikrine götürmez. Blondel'den ilham alarak geliştirdiği hareket felsefesi mistik bir dini tavra varır. "Topçu kurtuluşu, mistiğin ahlaki isyanında bulur."” Topçu için mistik önemli bir figürdür. Ulûhiyet ile bağ kurarak şahsiyetini oluşturmuş ahlaki bir kişiliktir mistik. Topçu’nun düşüncesinde din kadar merkezi bir konumda yer alan diğer bir unsur ise millettir.

\section{Topçu'nun Milliyetçiliği}

Nurettin Topçu kendisini milliyetçi olarak görür ve 1953 yılında kurulan Milliyetçiler Derneği'nin "bir nevi manevi başkanı" ${ }^{d}$ ır. Ancak Topçu’nun milliyetçiliği Ziya Gökalp’ın milliyetçiliğinden, Turancı milliyetçilikten ve Nihal Atsız’n ırkçı milliyetçiliğinden farklıdır. Topçu’nun milliyetçiliğini Anadolu milliyetçiliği olarak nitelendirebiliriz. Anadoluculuk akımı Birinci Dünya Savaşı'nın hemen ertesinde mütareke yıllarında ortaya çıkmış bir milliyetçilik olarak karşımıza çıkar. ' İmparatorluk coğrafyasının dağılmasıyla ve Avrupa’dan yayılan ulus fikrinin Osmanlı aydınları arasında yaygınlaşması ile eriyen imparatorluğun kurtuluşu olarak öne sürülen bu fikir, daha sonra cumhuriyet döneminde de farklı biçimler alarak devam etmiştir.

Topçu’nun Anadoluculuk anlayışında etnik unsur ile inanç unsuru karışmış bir haldedir. Topçu için Türk milletini oluşturan esaslar “...madde bakımından Anadoluınun coğrafyası üzerinde yaşayan bir çiftçi millet varlığı, ruh bakımından İslâm'ın bu millete sunduğu ruh ve ahlak örgüsü” ${ }^{10}$ dür. Türklerin Anadolu'ya gelmesi ile bu coğrafyaya İslâm aşısı vurulmuş ve daha önce çiftçilik ve hayvancılığın hâkim olduğu coğrafyada ruhsal unsur da yerleşmiştir. Bu birleşimle coğrafya, toprağa dayalı iktisadi faaliyet ve İslâmiyet’in birleşimiyle Anadolu bir kendilik olarak var olmuş ve Türk milletinin mekânı olmuştur. Köylülük Topçu’da yalnızca bir meslek olarak anılmaz. Köy’ün sunduğu pastoral yaşam içerisinde insan doğa ile irtibatını

4 Nurettin Topçu, Bergson, (İstanbul: Dergâh Yay.,2006) Eserin ilk basımı Hareket Yayınlarından 1968 yılında yapılmıştır.

5 Topçu'nun doçentlik tezi ile ilgili daha fazla bilgi için Bkz. Ali Birinci, "Nurettin Topçu’nun Bergson'la İlgili Doçentlik Tezi Hakkında Bilgiler ve Vesikalar”, Kutadgubilig Felsefe-Bilim Araştırmaları Dergisi 26 (2014), 253274.

6 Topçu'nun eserlerinin listesi için Bkz. Kara, "Ahlâk Davasına ve Muallimliğe Adanmış Bir Ömür: Nurettin Topçu", $18-23$.

7 Ali Osman Gündoğan, “Topçu ve Hareket Felsefesi”, Hece Aylık edebiyat Dergisi 109 (2006), 21.

8 Erverdi, Nurettin Topçu: Dünden Kalanlar ve Geleceğe Umutlar, 54.

9 Bkz. Hilmi Ziya Ülken, Türkiye’de Çağdaş Düsünce Tarihi, (İstanbul: Ülken Yay., 1992) 477.

10 Nurettin Topçu, Yarınki Türkiye, (İstanbul: Dergâh Yay., 2007), 142. 
koparmamıştır. Köy, emeğin meta haline gelmediği, dayanışmacı bir toplumsallık ile teknolojinin hâkimiyetinden ziyade doğanın ve insan iradesinin hâkim olduğu bir yaşama dünyasını imler. Organik bir toplumsallık biçimidir köy ve taşra. Topçu’nun Türk milletinin mekânı olarak gördüğü Anadolu, henüz kapitalistleşmemiş, sanayileşmemiş, tekniğin hâkimiyetine girmemiş, dinin saf haliyle yaşandığı bir mekândır. Kırsalın ve kırsalda yaşayan köylünün metafizik bir boyutu vardır. “...çiftçi veya köylü, bir yandan sadeliğe ve samimiliğe vurgun yaşamış, öbür yandan, varını kumarla biriktirmeyen hakikî sahip hüviyeti yaşatmış ve bu hüviyetin sabırlı ve nasibine razı oluş değerleriyle ayakta tutmuştur... Tabiatla sürekli bir kaynaşma içinde yaşayan, ruhunu tabiatlaştıran ve tabiatı ruhlaştıran bu insanın iş ahlâkı Anadolu'da İslam'ın başka yerlerde veremediği tabiat metafiziğini yaratmış, onu halk destanlarıyla beslemiştir." ${ }^{11}$ Kapitalist üretim biçiminin hakim olması ile beraber sermayenin mekanı haline gelen şehirlerde oluşan yeni yaşam biçimi ise insanın şahsiyetini oluşturmasına imkan sağlamaz, doğa ile insan arasındaki birliği bozar ve kozmopolit bir kültürel yaşam yarattığı için de milli kültüre katkıda bulunmaz. Bu kozmopolit yaşam içerisinde yetişmiş olan entelektüel ise milletin ruhuna herhangi bir katkı sağlayamaz. "Şehirlerin ve devlet kapılarının yetiştirdiği sözde münevver, bu memleketin sahibine hiçbir şey verememiştir." ${ }^{12}$ Milli kültürün mekanı taşradır ve taşrayı tanımayan, bilmeyen, ona yabancı olan entelektüeli organik entelektüel ${ }^{13}$ olarak görmez Topçu. Bu açıdan Topçu, milleti yalnızca etnik köken bakımından aynı olan insanların topluluğu olarak görmez. Bu bakımdan Turancı milliyetçilikten ayrılır ve Turancı görüşü sert bir şekilde eleştirir. "içtimaî realiteye boyun eğmeyi ahlak ideali haline getiren Ziya Gökalp, son nesillerimizin ideal yaratmaktan aciz, bitkin ruhunun mesullerinden sayılır. Onun ideal yaptığı Turan hayali de, muhtevası olmadığından... çocuk rüyası halinde zihinlere sunularak sade muhayyile macerası halinde kalmış bir davadır. "14 Topçu için Turancılık fikri Anadoluya uygun değildir. "Anadolu'da Turan'ın felsefesi yapılmaz, Fırat kıyılarında step edebiyatı yaşayamazdı." ${ }^{5}$ Aynı şekilde İslamcılık fikrine de mesafelidir. "İslamcılar, bu memleket çocuğunu yetiştiren emek ve toprağın hakkını inkâr ettiler...memleket çocuğu, zaman zaman soydan ve vatandan ayrı İslamcılık, yine vatan toprağından kaçan Turancılık gibi bedenden ve kalpten ayrılmış sevdalar peşinde koşmaktan yorulmuş, aldanmış ve memleket mukadderatını her biri bir devirde aldatmıştır." ${ }^{\prime 6}$ Irkçılık ise yalnızca maddi unsuru temel aldığı için de, millet fikrini doğru bir şekilde ifade etmez. Bu noktada Türk ırkçılığına mesafeli olan Topçu, konu Yahudilere geldiği zaman ırkçı diyebileceğimiz bir tutum sergiler.

\section{Topçu'da Anti-Semitizm ve Milliyetçilik}

Topçu'nun düşüncesinde biyolojik anlamda bir ırkçılığın bulunmadığını hatta bu türden bir ırkçılığı materyalist bir temele dayandığı için şiddetli bir şekilde reddettiğini söyleyebiliriz.

11 Topçu, Yarınki Türkiye, 119.

12 Topçu, Yarınki Türkiye, 120.

13 Burada organik entelektüel ifadesi Gramsci'nin organik aydın nitelemesi ile ilişkili olarak düşünülebilir. Topçu'nun organik aydını burjuva sınıfının ya da işçi sınıfının tarihsel bloğunun bir parçası değildir ama köylülüğün bir parçasıdır.

14 Nurettin Topçu, İradenin Davası Devlet ve Demokrasi, (İstanbul: Dergâh Yay.,2004), 21.

15 Nurettin Topçu, Türkiye’nin Maarif Davası, (İstanbul: Dergâh Yay., 2006), 29.

16 Topçu, Yarınki Türkiye, 134. 
Ancak Topçu'da kültürel anlamda bir ırkçılığın bulunduğunu iddia etmek için yazılarında yeterince veri olduğunu görülür. Özellikle Yahudiler ile ilgili sözleri kesif bir anti-semit olduğunu kanıtlar niteliktedir. Topçu'nun doçentlik tezini üzerine yazacak kadar görüşlerini benimsediği Henri Bergson'un Yahudi olması, onun anti-semitizminin biyolojik bir ırkçılığa varmadığının göstergesidir. Topçu, Yahudiliği yer yer kapitalizm ile özdeşleştirse de, Yahudi kimliğini kapitalizm eleştirisinden öteye taşır ve insanlığın uğradığı felaketin baş sorumlusu olarak görür. Topçu'nun anti-semitik yaklaşımlarına eserlerinden küçük iki örnek vermek ondaki anti-semitizmi görmek için yeterlidir: "Yahudi ise ne hukuki, ne ahlaki varlığı olmayan bir bezirgandır. Ne düşünen, ne de yapan insandır; o alıp satan adamdır; yani büyük pazarların dolandırıcısıdır. Gözleri kamaştıran para kuvveti arkasından bütün milletleri sürüklemek suretiyle bugün insanlığ uçurumların en müthişine götürmektedir. Dünyanın hiçbir tarafında milli devlet bırakmamaya kararlı olan Yahudi yumruğu mason teşekkülleri halinde ve zehirleyici bir kasırga gibi dünyayı dolaşıyor. İnsanlık bu büyük belaya karşı birlik halinde teşkilatlanıp da seferber olmazsa, yarını karanlıktır." "Yahudilerin hiçbir millete ve böylelikle hiçbir yerde insanlığa dost olmadıkları apaçık bir hakikattir." ${ }^{18}$ Ancak bu anti-semitizm Nazizmdeki gibi Yahudilerin imhasını bir yol olarak görmez. Bu açıdan Topçu'nun anti-semitizmi şiddet unsurunu barındırmayan bir antisemitizmdir.

Topçu'nun hoş görmediği tek etnik grup Yahudiler değildir. Aynı zamanda diğer bazı etnik gruplara yönelik olumsuz görüşleri olduğunu da söyleyebiliriz. "Nurettin Topçu'da bir popülist olarak yabancı düşmanlığı ve bu bağlamda ortaya çıkan komplo teorilerini sık bir şekilde gözlemlemek mümkündür." ${ }^{19}$ Topçu'nun yazdığı öykülerin analizinden şöyle bir sonuç çıkmaktadır: "Arap, Boşnak, Arnavut, Çerkez ve Girit kökenli İmparatorluk halkı, kendilerine kucak açan Anadolu’ya ve Anadolu insanına karşı her zaman kötü duygular, düşünceler beslerler ve her firsatta kötülük yaparlar. Nerede değerden yoksunluk ve bir alçaklık varsa onlardan birisi oradadır. Öykülerin kötü, alçak, namussuz, fırsatçı, hiçbir değer yargısı tanımayan tiplemeleri ya Arap, ya Çerkez, ya Arnavut ya da Boşnak'tır."20

Topçu Anadolu’yu mistik bir coğrafya olarak kurarken, yeni kurulmuş Cumhuriyetin sınırları içerisinde yaşayan Müslüman Türk etnik kimliğini millet ile özdeşleştirir. Bu bakımdan Pantürkizm'den ve Panislamizm'den ayrılır. Cumhuriyet ile kurulan ulus-devletin resmî ideolojisi ile uyumlu olan bir millet anlayışı ile karşılaşırız Topçu'da. Yazılarında Cumhuriyetin kurucu kadrolarının politik eğilimlerine yönelik bir eleştiri izlenimi edinsek de bu noktada ulus inşası çabası içerisindeki kurucu ideoloji ile bu noktada örtüştügüün̈ söyleyebiliriz. Topçu’nun cumhuriyetin kurucu kadrolarının siyasal yaklaşımlarına yönelik temel eleştirisi, bu kadroların siyasal yaklaşımlarının seküler modernist temelli bir tasavvura dayanmasıdır. Batı düşüncesinin model alınarak bir modernleşme çabasına yönelik eleştirisinde Topçu, batının örnek alınmasını kökten eleştirmez. Bu bakımdan Topçu için batı dünyası ve düşüncesi özsel olarak olumsuzlanmasını

17 Topçu, Iradenin Davası Devlet ve Demokrasi, 115-116.

18 Topçu, Yarınki Türkiye, 130.

19 Süleyman Seyfi Ögün, Türkiye’de Cemaatçi Milliyetçilik ve Nurettin Topçu, (İstanbul: Dergâh Yay., 1992) 119.

20 Hüseyin Su, "Yarınki Türkiye’nin Öyküleri”, Hece Aylık Edebiyat Dergisi 109 (2006), 353. 
gereken bir dünya değildir. Topçu'nun düşüncesi Şarkiyatçı söylemin oluşturduğu DoğuBatı dikotomisinin dışında kalır. Modernleşen, sekülerleşen, sanayileşen, kapitalistleşen Batı karşısında bir de mistik olan Batı, ruhun rönesansını yaşamış olan Batı, pastoral bir Batı, ruhçu bir Batı vardır. Bu bakımdan Topçu'nun düşünce dünyasındaki karşıtlık Doğu-Batı karşıtlığı değil; modern olan ile mistik olan, rasyonelleşmiş olan ile romantik olan, kapitalistleşmiş olan ile prekapitalist olan arasındaki karşıtlıktır. “Topçu'nunki klasik bir Doğu-Batı sorunu değil...bir 'aşkın yurtsuzluk' durumu ya da modern teknolojinin otantik varoluşu tehdit ettiğini vurgulayan Heidegger'in 'Varlık'ın unutulması' sorunudur. "21 Topçu bu karşıtlıklar içerisinde mistik olanın, romantik olanın, kapitalist olmayanın tarafındadır. “...romantizm hareketi, Batı’nın gençliği idi. O gençliğe ihtiyar küremiz her zaman hayrandır." ${ }^{22}$ Batı'da gerçekleşmiş olan romantizmin bir gün Anadolu'da da doğmasını beklemektedir. ${ }^{23}$ Onun için Anadolu'nun kurtuluşu mistiklerin yaratacağı bir romantizmdir.

\section{Topçu'nun Devlet Anlayışı}

Topçu için devlet, yurttaşların refahını ve bireysel hak ve özgürlüklerini koruyan siyasal bir organizasyon değil, bunu aşan etik bir idealdir. Şahsiyetlerin bir araya gelerek oluşturduğu toplumsal yapı ancak bir devlet teşekkül ettirdiği takdirde manevi bir anlama kavuşur. İnsan topluluklarını bir yığın olmaktan çıkartıp onların birliğine mana sağlayan şey devlettir. Devlet ile mutlak varlık arasında sıkı bir ilişki vardır. Kişi ancak devletin bir üyesi olması sayesinde gerçek anlamına kavuşur." Fert kendini ancak bir devlet iradesinde tamamlanmış hisseder. Fertten çıkarak sonsuzluğa doğru ilerleyen irade, yeryüzünde devlet iradesiyle tamamlanıyor." ${ }^{24}$ Yalnızca kişinin şahsiyetinin değil aynı zamanda toplumun da gerçek anlamda tamamlanması devlet aracılı̆̆ıyla gerçekleşir. "Devlet fertten Allah'a götüren yoldaki bir durak yeridir. Topluluk ancak devlet olduğu zaman, manevi bir varlık değerini kazanır." ${ }^{25}$ Bu nedenle Topçu'nun düşüncesinde devlet denilen siyasal organizasyon ne sınıflar arasındaki çatışmada egemen sınıfın yönetsel bir aygıtıdır ne de bireylerin doğal haklarını korumak ve çıkarlarını gerçekleştirmek üzere oluşturdukları bir siyasal organizasyondur. Bu açıdan Topçu, ne Marksist ne de liberal siyaset teorilerinin devlet anlayışını benimser. Topçu devleti manevi, metafizik bir temelde ele alır. Devlet, insanı sonsuz olana taşıyan bir kurumdur. Sonlu bir varlık olan insanın sonsuz olan ile ilişkisi ancak devlet sayesinde gerçekleşir. "Devlet, fertlerle Allah arasındaki bir bağ, kurulmuş bir köprü sayılabilir. Hayatımızı daha yüksek bir hayata ulaştıran, onun hayatı olur." ${ }^{26}$ Bu noktada Topçu'nun devlet anlayışında Hegel'in devlet anlayışının bir etkisini görebiliriz. Hegel'in devlet anlayışında da "Devlet özgürlügüun, e.d. saltık son ereğin olgusallaşmasıdır ve kendi uğruna varolur; ve yine anlaşılmalıdır ki, insan taşıdığı tüm değeri, tüm tinsel edimselliği yalnızca Devlet yoluyla taşır

21 Fırat Mollaer, "Nurettin Topçu İçin Bir Entelektüel Biyografi Denemesi”, Nurettin Topçu içinde Der. İsmail Kara (Ankara: Kültür Bakanlığı Yay.,2009), 49.

22 Topçu, Türkiyénin Maarif Davası, 17.

23 Bkz. A.e., 78.

24 Topçu, İradenin Davası Devlet ve Demokrasi, 166.

25 A.e., s. 47

26 A.e., $s .48$ 
(...) Devlet yeryüzünde bulunduğu gibi tanrısal İdeadır." ${ }^{27}$ Hegel'deki gibi mantıksal ve ayrıntılı bir serimleme yapmasa da, devleti mutlak olan ile ilişkiye sokmasında ve neredeyse devleti mutlak iradenin bir yansıması olarak görmesi ile ortak bir nokta olarak değerlendirilebilir. Devleti, içkin bir alandan aşkın bir kaynağa bağlayan ve otoriteyi kamusallıktan çıkarıp sonsuz olan ile ilişkilendiren Topçu'nun devlet tasavvuru bu nedenle otoriter bir tona sahiptir.

\section{Topçu'nun Demokrasi Eleştirisi}

Topçu "Demokrasi, gerçek milliyetçiliğin idare sistemi olamaz." ${ }^{28}$ diyerek kendi milliyetçiliğinde demokrasinin yeri olamayacağını belirtir. Topçu için egemenliğin yegâne kaynağı yurttaşların iradesi değildir. “...hakimiyet veya otoritenin kaynağı nerededir?...bir tarafta milletin hayatından doğar...fertlerden doğarak bir anda fertlerin üstüne yükselir. Fert için mukaddesat kaynağı olur. Onun diğer kaynağ olan unsurların, yani insan fertlerinin bütünü açıklanamaz.. ${ }^{29}$ Bu bakımdan siyasal otoritenin bir diğer kaynağı aşkın bir kaynaktır. Bu nedenle bu aşkın kaynak ile irtibatı bulunmayan kişilerin egemenliğin kullanımında söz sahibi olması uygun değildir. Siyasal gücü kullanacak olanlar mesuliyet sahibi olan kişiler olmalıdır. Siyasal gücün kullanımı tüm yurttaşlara terk edilemez çünkü halkın çoğunluğu yüksek ahlaki idealleri kavramaktan uzaktır. Halkın çoğunluğu kendi kişisel çıkarlarını öncelerler ve nefislerinin peşinde koşar. "Her yerde cahili âlimden, şahsı menfaat düşkünü faziletlisinden, nefsine düşkünleri hizmet ehli olanlarından kat kat fazla sayıda bulunan halk, toplum düzenini en iyi şekilde yürütmeye kabiliyetli değildir. Bu yüzden çoğunluğun oyuna başvurulan her yerde haksızlık ve kötülük kendini gösterecektir." ${ }^{30} \mathrm{Bu}$ açıdan çoğunluk iradesi her zaman hakkın iradesi anlamına gelmediğinden Hakk'ın iradesini hâkim kılacak bir otorite tarafından siyasal güç kullanılmalıdır. Bu noktada elitist bir siyasal anlayışa sahip olduğunu düşünebiliriz. “... elitist bir siyaset ve devlet anlayışına sahip olan Nurettin Topçu'nun eserlerinde eşitlik önemli bir kavram olarak yer almaz." ${ }^{31}$ Genel menfaati bilen ve bunu gerçekleştirmeyi amaç edinmiş olan ilahî olan ile bağlantısını kurmuş olan mistikler vasıtasıyla kurulacak bir yönetim mesuliyete dayalı bir yönetim olacağından herkesin hakkını gözetecek ve adil bir şekilde toplumu organize edecektir. Bu bakımdan yönetici halkın iradesine boyun eğen değil hatta kimi zaman onunla çatışan bir durumda olacaktır. "Bu büyük fertlerin ahlak iradesi, cemiyette her zaman halkın ahlakı istemeyen, hem de çok kere ahlak kıyafetine bürünerek ahlakı çiğneyen istek ve iradesiyle çarpışır...Daima sahnenin iç tarafında, ahlak kahramanlarıyla halkın boğuşması vardır...halk fazileti değil, saadeti istiyor."32

Parlamenter demokrasinin temel kabulü olan siyasal eşitlik fikrine de mesafelidir Topçu. Yurttaşların siyasal bakımdan eşit sayılmasının bir eşitsizlik doğurduğunu düşünür. “...bu

27 G.W.F. Hegel, Tarih Felsefesi, Çev. Aziz Yardımlı, (İstanbul: İdea Yay.,2006), 36.

28 Topçu, Iradenin Davası Devlet ve Demokrasi, 130.

29 A.e., 47.

30 A.e., 127.

31 İsmail Kara, "Bir Siyasi İhya Hareketi: Topçu'da Siyaset ve Devlet Telakkisi”, Hece Aylık Edebiyat Dergisi 109 (2006), 250.

32 Nurettin Topçu, İslam ve İnsan: Mevlana ve Tasavvuf, (İstanbul: Dergâh Yay., 2013), 90. 
rejimde 'bilenle bilmeyen bir' olmaktadır. Zira her vatandaş aynı oy hakkına sahiptir. Bu hususta cahille âlimin, filozofla amelenin, şerir ile velinin farkı tanınmıyor.”33

Topçu için parlamenter demokrasi bireysel çıkarların tatminine dayandığ 1 için yüksek bir ideali gerçekleştirmede başarılı olamaz. Kapitalist üretimin hâkim olduğu toplumlarda sermaye grupları daha etkin olduğu için siyasal partiler bu küçük grupların çıkarlarını genel çıkarmış gibi sunarlar. Dar siyasi grupların kendi menfaatini gerçekleştirmesine dayalı olan parlamenter demokraside halkın enerjisi ve heyecanı boş yere tüketilir. "Doğunun, ilim zihniyetini benimsememiş ve ödev iradesi ise asırların uyuşukluğu içinde çürümüş memleketlerinde, demokrasinin manzarası acıklıdır. Buralarda, seçim cambazlığına bağlanmış demokrasi gösterisi içinde halkın heyecan ve enerjisi harcanarak fert ve zümrelerin hırs ve menfaatleri ile gizli teşkilatlara bağlı despotik kuvvetlerin hazin bir karışımı yaşatılmaktadır. Milletleri bu kuvvetlerin pençesinden kurtaracak olan, otoriteye dayanan milliyetçi sosyalizmdir. " ${ }^{34}$ Kapitalizmin egemen olduğu toplumsal yapıda siyasal partiler sınıfların çıkarını gerçekleştirme amacını taşırlar. "Halk içinde şahsi menfaatlerini, yani küçük ve göze görünmez istibdatlarını hâkim kılmak isteyenler, partiler kurar, partilerin içinde zümreler ve köşeler meydana getirirler. Mümessil salahiyetle meclise girerler. Bunların meclisi, sade kendi emellerinin basamağı olacağından, millete bunlardan iyilik gelmez. Burada, her zümrenin millet saadet ve varlığından bir avuç kapmasını temin eden fikirler kanunlaştırılır. Memleket bunlar tarafından sömürülür, geriler ve sahibini arar." ${ }^{35}$

Topçu için parlamenter demokrasi aynı zamanda toplumu ahlaki bakımdan da gerileten bir siyasal sistemdir. "Demokrasinin gerçek şekli olan çok partili rejim devrinde vatandaş ahlakının düştüğünü görüyoruz." ${ }^{6}$ Parlamenter demokrasinin ahlaki zaafa yol açmasının nedeni, insanların şahsi çıkarlarının, grup çıkarlarının, maddi çıkarlarının peşinde koşarak manevi olandan uzaklaşmalarına neden olmasıdır.

Topçu için demokrasinin bir diğer olumsuz yanı toplumun bilgili ve kültür sahibi üyelerini aşağı çekmesidir. Yüksek kültürel ve ahlaki bilince sahip kişileri çoğunluğun seviyesine indirmesidir. "İçtimaî sınıf imtiyazlarını, nihayet irade ve değerler sahasında ortadan kaldıran modern demokrasi...zararlı sonuçlar doğurdu. Aşağı sınıf halkı tutup kültürlü insanların seviyesine doğru yükseltecek ve o seviyenin frenleriyle bütün bir hayatı bir tempoda yürütecekken, üstün seviye ve kültür sahiplerini halkın hizasına indirdi; onların iradesini halkın emrine verdi." ${ }^{77} \mathrm{Bu}$ sözlerinden de anlaşılabileceği gibi Topçu, halk ile millet mistikleri adını verdiği kişiler arasında hiyerarşik bir ilişki olması gerektiğini savunur. Bu nedenle kurtuluşun yolu "Bizi, hepimizi devlete konma vaadleri ile oyalayıp sarhoş ederek seçimler bekleten particilik rejimleri değil, hakikatı, sanatı, ahlakı yükselterek insanlığı Allah’a doğru götürecek mesul insanların irade kudretine dayanan hâkimiyetler" ${ }^{38}$ dir.

\footnotetext{
33 Topçu, İradenin Davası Devlet ve Demokrasi, 120.

34 A.e., 121-122.

35 Nurettin Topçu, Ahlak Nizamı (İstanbul, Dergâh Yay.2008), 21.

36 Topçu, Iradenin Davası Devlet ve Demokrasi, 133.

37 Topçu, Türkiyénin Maarif Davası, 91.

38 Topçu, Iradenin Davası Devlet ve Demokrasi, 132.
} 
Topçu parlamenter demokrasi yerine getirdiği öneri şudur: "Devlet programı ,devlet teşebbüsü ve devlet kontrolüne dayanan; devletin ortak işleteceği mahalli kooperatiflerin sermayesini kullanan, köylünün emeği ile çalışan, kârına köylüyü ortak yapan sosyalist sistem. Bu sosyalizm, ana unsur olarak fabrika amelesini değil, işlettiği toprağın asıl sahibi olan toprak işçisini, yani köylüyü alacaktır. Ticaret hayatında ise loncaların yeni görüş ve ihtiyaçlara uygun olarak canlandırılması lazımdır."39

\section{SONUÇ}

Topçu'nun parlamenter demokrasi eleştirisi onun kapitalizm eleştirisinin de bir sonucudur. Kapitalist üretim biçiminin parçalayıp yok ettiği feodal üretim biçimine dayalı bir siyasal örgütlenme yerine, burjuva sınıfının yeniden biçimlendirdiği siyasal alanın temel öğesi olan parlamenter demokrasi fikrine itiraz eder. Topçu’nun düşüncesinde bulunan güçlü kapitalizm eleştirisi, onu Marksist bir eleştiriye götürmez. Marksizm diyalektik bir materyalizme dayandığı için reddedilir. Topçu için "Rus Komünizmi dünyamızda kapitalizm rejimine tepki olan, tarihimize yabancı, milletimin mukaddesatına düşman bir davadır. Bunlar iradeyi büsbütün inkâr ederek, konusu hayattan ibaret ekonomik gerçekliğe bağlanan realistlerdir.” ${ }^{40}$ Topçu parlamenter demokrasi fikrini prekapitalist bir toplumsal yapı tahayyülüne bağlı olarak eleştirdiği için İslâmî bir içerikle donanmış kişi iradesine dayalı otoriter bir yapılanma önerir. Kapitalist üretim biçimi ve onun yarattığı toplumsal siyasal örgütlenme modelinde, insanın araçsallaşması ve emeğin yerine sermayenin en üstün değer sayılması sonucu insanın kendi varlığına yabancılaşmasına yönelik bir itirazdan bulunan Topçu, bu yabancılaşmanın ortadan kaldırılmasını korporatif bir devlet sisteminde görür. Bu noktada "Devlet, dayanışma hareketinin şuuru olmalıdır. Devletin üstüne aldığı vazife, insanî ve evrenseldir. Onun görevi, ferdî hareketin verimini toplamak ve evrensel olabilmek için ona yeterli güç ve enerjiyi sağlamaktan ibarettir." ${ }^{11}$ "Devlet, büyük çoğunluğu köylü olan kütlenin iradesini yaşatan merkeziyetçi, otoriteli ve mesuliyetli devlettir.” ${ }^{42}$ Sonsuz olan ile ilişki içerisinde olan bir otorite tarafından, topluma ruhçu ilkelere göre şekil veren yüksek ahlaki ilkeleri takip eden bir lider ve meslek örgütlerinin temsilcileri ile birlikte yönetim işlevinin gerçekleştiği bir siyasal yapıyı önerir. Topçu'daki otoriter bir siyasal yapıya dayalı bu romantizm neredeyse faşizme dayanacaktır. Ancak Topçu'nun bu yaklaşımını faşizmden ayıran şey kategorik olarak siyasal şiddetin reddidir. İslami bir sosyalizm önerisinde bulunan Topçu'da İslam inancı merkezi bir konum teşkil etmesine rağmen, bu İslam anlayışı şiddeti reddeden bir anlayıştır. "İslam’ı yükseltmek için kin, kılıç ve şiddet silahlarını kullananlar Allah yolunun dışında dolaşan gerçek imansızlardır.” ${ }^{33}$ Oldukça ateşli bir antikomünist olan Topçu, komünist gençlere karşı şiddet uygulanmasını son derce yanlış bulur ve bunu sesli bir biçimde dile getirir. "Amerika komünizme düşmandır; komünizmde Müslümanlığa düşman olduğu için Amerika’yı desteklemek her Müslümanın üzerine vaciptir; bu belki de bir cihaddır. Desteklemek için ne

\footnotetext{
39 Topçu, Yarınki Türkiye, 150.

40 Topçu, Iradenin Davası Devlet ve Demokrasi, 21.

41 Nurettin Topçu, İsyan Ablakı, Çev. Mustafa Kök, Musa Doğan (İstanbul: Dergâh Yay., 2006), 91.

42 Topçu, Yarınki Türkiye, 151.

43 Topçu, İslam ve İnsan: Mevlana ve Tasavvuf, 99.
} 
lazımsa yapılır, gayeye varmak için adam öldürmek caiz olur; hele öldürülen komünist ise... Biz, İslam aleminin bütün sefaletler mahşeri olan bugünkü haline sebep olarak, asırlardır din adına yapılan zülüm ve zilletleri görmekte haklı olduğumuza inanıyoruz." ${ }^{4} 4$ Topçu'nun İslam anlayışında diğer gruplara yönelik şiddet İslam ile bir araya gelmeyecek şeylerdir. "Kin ile dinin bir damlasının bile yanyana barınmayacağını her iki taraftan bilen, anlayan bulunmuyor." ${ }^{35} \mathrm{Bu}$ açıdan demokrasi eleştirisi faşizm ile sonuçlanmaz. Topçu'nun Alman faşizminin lideri olan Adolf Hitler' in siyasal ideolojisi olan Nasyonel Sosyalizmi takdir eder. "Hitler, ideali hülyaya çiğnetti." ${ }^{46}$ diyerek nasyonel sosyalizmin idealini doğru bulduğunu ima eder. Topçu Hitler'in fotoğrafını yaşamının sonuna kadar çalışma odasında asılı olarak tutar. Alman nasyonel sosyalizmden esinlenmiş ancak onu tüm unsurları ile benimsediğini söylemek mümkün değildir. Nasyonel sosyalizm Topçu için "Doktriner bir besin kaynağ 1 değilse de, bir ilham kaynağ $1{ }^{47}$ dır. Siyasal şiddeti reddetmesi ile bu noktada Alman nasyonel sosyalizminden ayrılır. Faşizmden ziyade popülist bir romantizme daha yakındır. Topçu'nun parlamenter demokrasiye yönelik bu eleştirisi popülist romantizm ile eklemlenebilir. "Romantizmin bu biçimi hem sanayi kapitalizmine hem de monarşiye ve köleliğe karşıttır ve modern-öncesi 'halk'ın köylü ve zanaatkâr cemaat yaşamı ile üretim biçimlerini toplumsal başkalık olarak kurtrmaya, onarmaya ya da geliştirmeye özlem duyar...Bu kapitalizm eleştirisi sürekli olarak pre-kapitalist bir altın çağa göndermede bulunduğundan ve korporatist ya da cemaatçi türde yapılar içerisinde bir araya gelmiş küçük zanaatkarların ve mülk sahibi köylülerin patriarkal bir toplumunu hayal ettiğinden romantiktir.”48

Hakem Değerlendirmesi: Dış bağımsız.

Çıkar Çatışması: Yazar ç̧ıar çatıșması bildirmemiş̧,ir.

Finansal Destek: Yazar bu çalışma için finansal destek almadığını beyan etmiştir.

Peer-review: Externally peer-reviewed.

Conflict of Interest: The author has no conflict of interest to declare.

Grant Support: The author declared that this study has received no financial support.

\section{Kaynaklar / References}

Birinci, Ali. "Nurettin Topçu'nun Bergson'la İlgili Doçentlik Tezi Hakkında Bilgiler ve Vesikalar", Kutadgubilig Felsefe-Bilim Araşttrmaları Dergisi 26 (2014), 253-274.

Tanıl Bora, "Nurettin Topçu'da Anti-Kapitalizm ve Sosyalizm Pis Burjuva ve Kul Hakkı", 40 Yıl Sonra Nurettin Topçu: "Nurettin Topçu Bugün Bize Ne Söyler?” Der. Musa Kazım Arıcan, Mustafa Orçan, Muhammed Enes Kala, 78-84. Ankara: Türkiye Yazarlar Birliği Yayınları, 2016.

44 Topçu, Iradenin Davası Devlet ve Demokrasi, 225.

45 Topçu, İslam ve Insan: Mevlana ve Tasavvuf, 24.

46 Topçu, İradenin Davasi Devlet ve Demokrasi, 203.

47 Tanıl Bora, "Nurettin Topçu'da Anti-Kapitalizm ve Sosyalizm Pis Burjuva ve Kul Hakkı", 40 Yıl Sonra Nurettin Topçu: “Nurettin Top̧̧u Bugün Bize Ne Söller?” Der. Musa Kazım Arıcan, Mustafa Orçan, Muhammed Enes Kala, (Ankara: Türkiye Yazarlar Birliği Yayınları, 2016), 79.

48 Michael Löwy, Robert Sayre, İsyan ve Melankoli: Moderniteye Karşı Romantizm, Çev. Işık Ergüden (İstanbul: Alfa Yay., 2016), 112-113. 
Ezel Erverdi, Ezel. Nurettin Topçu: Dünden Kalanlar ve Geleceğe Umutlar. İstanbul: Dergah Yay, 2018.

Gündoğan, Ali Osman. “Topçu ve Hareket Felsefesi”, Hece Aylık edebiyat Dergisi 109 (2006): 15-22.

Hegel, G.W.F. Tarih Felsefesi. Çeviren Aziz Yardımlı. İstanbul: İdea Yay.,2006.

Kara. İsmail. "Ahlâk Davasına ve Muallimliğe Adanmış Bir Ömür: Nurettin Topçu”, Temaşa Erciyes Üniversitesi Felsefe Bölümü Dergisi 4 (2016): 6-23.

Kara, İsmail. “Bir Siyasi İhya Hareketi: Topçu'da Siyaset ve Devlet Telakkisi”, Hece Aylık Edebiyat Dergisi 109 (2006): 244-254.

Löwy, Michael, Sayre, Robert. İsyan ve Melankoli: Moderniteye Karşı Romantizm, Çeviren Işık Ergüden. İstanbul: Alfa Yay., 2016.

Mollaer, Fırat. "Nurettin Topçu İçin Bir Entelektüel Biyografi Denemesi”, Nurettin Topçu içinde Der. İsmail Kara, 22-61. Ankara: Kültür Bakanlığı Yay.,2009.

Öğün, Süleyman Seyfi. Türkiye’de Cemaatçi Milliyetçilik ve Nurettin Topçu. İstanbul: Dergah Yay., 1992.

Su, Hüseyin. "Yarınki Türkiye’nin Öyküleri”, Hece Aylık Edebiyat Dergisi 109 (2006): 349-356.

Topçu, Nurettin. Türkiye’nin Maarif Davası. İstanbul: Dergah Yay., 2006.

Topçu, Nurettin. Bergson. İstanbul: Dergah Yay.,2006.

Nurettin Topçu, Ablak Nizamı. İstanbul, Dergah Yay.2008

Topçu, Nurettin. İradenin Davası Devlet ve Demokrasi. İstanbul: Dergah Yay.,2004.

Topçu, Nurettin. İslam ve İnsan: Mevlana ve Tasavvuf. İstanbul: Dergah Yay., 2013.

Topçu, Nurettin. İsyan Ahlakı, Çeviren Mustafa Kök, Musa Doğan. İstanbul: Dergah Yay., 2006.

Topçu, Nurettin. Yarınki Türkiye. İstanbul: Dergah Yay., 2007.

Ülken, Hilmi Ziya. Türkiye’de Çăgdaş Düşünce Tarihi, İstanbul: Ülken Yay., 1992. 
